\title{
Anaerobic metabolic strategy of the glacial relict isopod Saduria (Mesidotea) entomon
}

\author{
Lars Hagerman ${ }^{1}$, Anna Szaniawska² \\ ${ }^{1}$ Marine Biological Laboratory, Strandpromenaden 5, DK-3000 Helsingør, Denmark \\ ${ }^{2}$ Oceanographical Institute, Gdansk University, Al. Czolgistow 46, 81-378 Gdynia, Poland
}

\begin{abstract}
The glacial relict isopod Saduria (Mesidotea) entomon (L.) was kept under anoxia for up to $300 \mathrm{~h}\left(\mathrm{~S}, 7 \% ; \mathrm{T}, 8^{\circ} \mathrm{C}\right)$. Glycogen was found in normoxic concentration of 20 to $30 \mu \mathrm{mol} \mathrm{g} \mathrm{g}^{-1}$ dry wt; it decreased rapidly in anoxia for the first $100 \mathrm{~h}$, after which the decrease slowed. The glycolytic flux decreased after $100 \mathrm{~h}$ by a factor of 10 . Blood glucose increased during the period of high glycolytic flux, but, corresponding to the decrease in glycolytic flux after $100 \mathrm{~h}$, it decreased again, remaining however above normoxic values. $S$. entomon forced to be active under anoxia accumulated lactate, but when quiescent showed practically no increase in lactate. Quiescent $S$. entomon showed a steady accumulation of alanine, which inhibits the activity of pyruvate kinase and is thus responsible for the reduction in glycolytic flux. This anaerobic strategy, which makes it possible to survive extended periods of anoxia, is unique among crustaceans.
\end{abstract}

\section{INTRODUCTION}

The isopod Saduria (Mesidotea) entomon (L.) occurs in the deeper waters in the Baltic, normally buried in the sediment. It is a very eurybiontic species showing extremely high tolerances to anoxia and salinity variations, whilst temperatures above 12 to $15^{\circ} \mathrm{C}$ are lethal (Hagerman \& Szaniawska unpubl.). The metabolic rate is low with a high efficiency of oxygen extraction making it possible to maintain a stable $\mathrm{MO}_{2}$ respiratory rate down to 5 or 10 Torr (Hagerman \& Szaniawska 1988). Even at low $\mathrm{p}_{\mathrm{w}} \mathrm{O}_{2} S$. entomon seems to be active, undertaking digging and feeding.

Anaerobic metabolism, starting when oxygen extraction can no longer be maintained, results in only a slight increase in haemolymph lactate with time in Saduria entomon (Hagerman \& Szaniawska 1988). This is surprising as lactate is normally the only endproduct of anaerobic glycolysis in crustaceans (de Zwaan \& Putzer 1985). In a few crustaceans, Cirolana borealis (de Zwaan \& Skjoldal 1979), Upogebia pugettensis and Callianassa californiensis (Zebe 1982), and the merostomate Limulus polyphemus (Carlsson \& Gäde 1986), signs of other fermentation products (alanine and succinate) have been found besides lactate. Most earlier experiments on crustacean anaerobic metabolism exposed the experimental animals to relatively short periods of hypoxia/anoxia, usually a few hours, up to
$48 \mathrm{~h}$. There is thus the possibility that $S$. entomon, unusually for a crustacean, uses another strategy of anaerobic metabolism than lactate-producing glycolysis. The purpose of the present work is to study patterns and changes of anaerobic metabolism in $S$. entomon under prolonged anoxic conditions.

\section{MATERIAL AND METHODS}

Saduria entomon were collected at depths greater than $15 \mathrm{~m}$ in the Gulf of Gdansk, Poland ( $\mathrm{S}, 7$ to $8 \%$; $\mathrm{T}$, $8{ }^{\circ} \mathrm{C}$ ), brought to Helsingør, Denmark by car and ship, and stored under the same temperature/salinity conditions. Specimens were fed twice weekly with shrimp meat. Anoxic conditions were maintained for up to 300 h by bubbling with $\mathrm{N}_{2}$. Oxygen tension was monitored continously with a Radiometer E 5047 oxygen electrode connected to a Radiometer PHM 73 acid-base analyser. In the anoxia experiments oxygen tension was always lower than 1 Torr.

Biochemical analyses. Glycogen: Saduria entomon were dried at 60 to $70^{\circ} \mathrm{C}$, pulverised, and subsamples of $100 \mathrm{mg}$ taken. These were boiled with $0.5 \mathrm{ml} 20 \% \mathrm{KOH}$ for $20 \mathrm{~min}$. After cooling, $5 \mathrm{ml}$ of $96 \%$ ethanol was added and the samples stored for $24 \mathrm{~h}$ in a refrigerator. After centrifugation the precipitate was extracted twice with $0.5 \mathrm{ml}$ TCA (trichloroacetic acid), combined and 
again precipitated with $2 \mathrm{ml}$ ethanol. The fluid was removed and the precipitate dissolved in $1 \mathrm{ml}$ distilled water. Glycogen was then measured by the anthronereagent method as described by Vooys (1987).

Aspartate was measured via aspartate-amino transferase (GOT; glutamic oxaloacetate transaminase) in the haemolymph following the Sigma Diagnostics procedure no. DG 158-UV. Presence of GOT in the haemolymph would indicate presence of aspartate in the tissues.

Alanine-aminotransferase was similarly measured following Sigma Diagnostics procedure DG 159-UV.

Lactate in haemolymph and water was analysed with Boehringer-Mannheim Test Kit 139084.

Glucose: Circulating glucose was analysed according to Sigma Diagnostic procedure no. 510.

Alanine in haemolymph and tissue was measured by HPLC (Perkin-Elmer Series 2) by pre-column reaction with orthophthaldehyde and fluorescence detection, according to Gardner \& Miller (1980).

Succinate: A haemolymph sample was taken or tissue was dissected in a beaker on ice and under a flow of nitrogen. The tissue was homogenised with 2 volumes ( $\mathrm{V} /$ w) cold $0.02 \mathrm{M} \mathrm{KOH}$-borate buffer $\mathrm{pH}$ 9.5. Double samples were weighed and deproteinised by the addition of the same weight of $6 \%$ ice-cold TCA. The samples were thereafter centrifuged at $12700 \times \mathrm{g}$ for $30 \mathrm{~min}$ at 4 ${ }^{\circ} \mathrm{C}$. A known volume of the supernatant was neutralised with $5 \mathrm{M} \mathrm{K}_{2} \mathrm{CO}_{3}$ with phenol-red as indicator. The succinate in the supernatant was then determined according to Boehringer-Mannheim Test Kit 176281.

Acetate: Circulating acetate was analysed using Boehringer-Mannheim Test Kit 148261.

With the exception of alanine, all these biochemical assays are based on methods described in Bergmeyer (1985). For practical reasons (amount of tissue, number of specimens) it was not possible to perform all assays on both tissue and blood (haemolymph). For assays performed on blood only it can be argued that if an endproduct of aerobic-anaerobic metabolism was produced in the tissues it would also be found in the blood.

\section{RESULTS}

The concentrations of substrates and metabolites at normoxia and after anoxic periods of up to $300 \mathrm{~h}$ are summarised in Table 1. Glycogen, expressed as dry weight $(\mathrm{dwt})$, including carapace weight, which constitutes ca $45 \%$ of wet weight, showed large individual variation (Fig. 1). A decrease from normoxic values took place with exposure to anoxia until, after ca $100 \mathrm{~h}$ of anoxia a stable low level around 3 to $5 \mu \mathrm{mol} \mathrm{g}^{-1} \mathrm{dwt}$ was reached. The mobilisation of glycogen was thus faster during the first $100 \mathrm{~h}$ of anoxia, being ca 0.25 $\mu \mathrm{mol} \mathrm{h}^{-1}$. Later the flux decreased by a factor of 10 , and approached $0.025 \mu \mathrm{mol} \mathrm{h} \mathrm{h}^{-1}$. A reduction to half the normoxic glycogen concentration had taken place by 48 h of anoxia.

Circulating glucose, which reflects the utilization of glycogen, increased considerably from normoxic $(150$ $\mu \mathrm{mol} 1^{-1}$ blood), rising after 100 to $120 \mathrm{~h}$ anoxia to 1400 $\mu \mathrm{mol} 1^{-1}$ blood (Fig. 2). The marked decrease after this period apparently corresponds to the change in glycolytic flux as seen in the lowered glycogen concentrations above.

Tissue aspartate (indirectly indicated by aspartateaminotransferase) was not detectable, nor was alanineaminotransferase as an indicator of the aspartate-alanine shuttle (de Zwaan \& Putzer 1985). Aspartic acid in the haemolymph was, however, found in small, varying quantities. Aspartic acid in haemolymph is part of the FAA-pool and used for isosmotic intracellular regulation.

Of the various anaerobic metabolites, succinate was not detectable even after $240 \mathrm{~h}$ anoxia either in tissue or blood, and acetate only in concentrations as low as 40 to $50 \mu \mathrm{mol} 1^{-1}$ blood.

Circulating lactate increased a little from normoxic 200 to $600 \mathrm{umol}^{-1}$ blood to generally 1000 to 2000 umol $1^{-1}$ blood after $240 \mathrm{~h}$ anoxia (Fig. 3) (see also Hagerman \& Szaniawska 1988). After the longest anoxic periods, decreased lactate levels were again evident. However, during the first $72 \mathrm{~h}$, some specimens had very high levels of lactate, from 8000 to

Table 1. Saduria entomon. Average concentrations ( \pm SD) of metabolic substrates and anaerobic metabolites in quiescent isopods after various exposure times to anoxia. In parentheses: sample size

\begin{tabular}{|c|c|c|c|c|c|c|c|}
\hline $\begin{array}{l}\text { Time in } \\
\text { anoxia (h) }\end{array}$ & $\begin{array}{c}\text { Glycogen } \\
\left(\mu \mathrm{mol} \mathrm{g}^{-1} \mathrm{~d} w \mathrm{t}\right)\end{array}$ & $\begin{array}{c}\text { Aspartate } \\
\left(\mu \mathrm{mol} \mathrm{g}^{-1} \mathrm{dwt}\right)\end{array}$ & $\begin{array}{c}\text { Glucose } \\
\left.(\mu \mathrm{mol}]^{-1} b .\right)\end{array}$ & $\begin{array}{c}\text { Lactate } \\
\left(\text { umol } L^{-1} \text { b. }\right)\end{array}$ & $\begin{array}{c}\text { Alanine } \\
\left(1 \mathrm{~mol} \mathrm{l}^{-1} \mathrm{~b} .\right)\end{array}$ & $\begin{array}{c}\text { Succinate } \\
\left(\mu m o l g^{-1} d w t\right)\end{array}$ & $\begin{array}{c}\text { Acetate } \\
(\text { mol })^{-1} \text { b.) }\end{array}$ \\
\hline 0 & $25 \pm 7.2(10)$ & nd $(6)$ & $100 \pm 34 \quad(6)$ & $325 \pm 140(5)$ & $80 \pm 55$ & nd (6) & nd $(5)$ \\
\hline 24 & $17 \pm 7.8(11)$ & nd (3) & $500 \pm 30$ & $820 \pm 165(4)$ & $90 \pm 36$ & nd (3) & nd (5) \\
\hline $72-96$ & $7 \pm 4.5(16)$ & nd $(6)$ & $890 \pm 47$ & $1525 \pm 763(4)$ & $280 \pm-87(10)$ & $\mathrm{nd}(6)$ & nd (4) \\
\hline 120 & $6 \pm 2.9(7)$ & nd (3) & $1150 \pm 42$ & $1300 \pm 874(3)$ & $425 \pm 183(2)$ & nd (3) & nd (3) \\
\hline 240 & $3.5 \pm 1$ & nd (5) & $195 \pm 105(3)$ & $500 \pm 420$ & $1300 \pm 350(4)$ & nd (5) & $44(3)$ \\
\hline 300 & $\mathrm{~nm}$ & $\mathrm{~nm}$ & $\mathrm{~nm}$ & $330 \pm 215(3)$ & $\mathrm{nm}$ & $n m$ & $\mathrm{~nm}$ \\
\hline
\end{tabular}


Fig. 1. Saduria entomon. Concentration of glycogen in tissue after various periods of anoxia

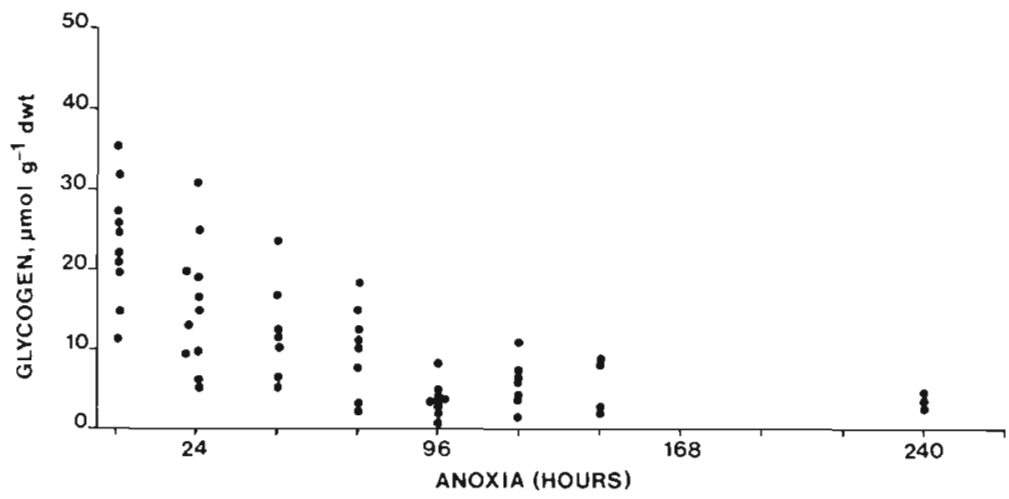

$14000 \mu \mathrm{mol} \mathrm{l}^{-1}$ haemolymph. It was suspected that the 'initial' high lactate levels were a result of swimming and other activity. To test this, some specimens were placed under anoxia and after $24 \mathrm{~h}$ forced to swim (by mechanical stimulation) and be continuously active for $8 \mathrm{~h}$. Lactate concentrations after this were in the range 5600 to $18200 \mu \mathrm{mol} 1^{-1}$, a clear indication that high lactate levels are caused by constantly high activity levels during anoxia, i.e. combined exercise and environmental anaerobiosis. Quiescent specimens, on the other hand, had almost no lactate accumulation. Most Saduria entomon are quiescent during anoxic periods. Excretion of lactate into the medium via pleopods or antennal glands was tested by keeping specimens in small volumes of anoxic water, with samples for lactate analysis taken every hour. No accumulation of lactate was found in the water, i. e. no excretion took place.

Alanine seems to be the main endproduct accumulating in Saduria entomon during prolonged anoxia (Fig. 4). From the normoxic 50 to $100 \mu \mathrm{mol} \mathrm{l}^{-1}$ a steady increase of $4.5 \mu \mathrm{mol} \mathrm{h}^{-1}$ took place to between 1100 and $1500 \mathrm{umol} \mathrm{l}^{-1}$ after $240 \mathrm{~h}$ anoxia. The normoxic concentration is in the range that can be explained by alanine in the FAA (free amino acids) for osmoregulatory purposes (Weber \& van Marrewijk 1972). Tissue alanine was analysed at normoxia and after $240 \mathrm{~h}$ anoxia. These values (mean) were $127 \mu \mathrm{mol} \mathrm{g}^{-1} \mathrm{dwt}(\mathrm{n}=4)$ and 1534 $\mu \mathrm{mol} \mathrm{g}{ }^{-1} \mathrm{dwt}(\mathrm{n}=4)$ respectively, thus reflecting the increase found in the haemolymph.

\section{DISCUSSION}

Glycogen is an important substrate for anaerobic metabolism in Saduria entomon. The concentration of glycogen seems to be a little lower than for many other crustaceans ( 20 to $30 \mu \mathrm{mol} \mathrm{g}{ }^{-1} \mathrm{dwt}$ as compared with 40 to $60 \mu \mathrm{mol} \mathrm{g}{ }^{-1} \mathrm{dwt}$ ) (de Zwaan \& Putzer 1985). The initial anoxic utilisation of glycogen is also lower and should be compared with the burrowing Upogebia pugettensis using $0.83 \mu \mathrm{mol} \mathrm{h}{ }^{-1} \mathrm{~g}^{-1}$ wet weight for the first $24 \mathrm{~h}$ of anoxia (Zebe 1982) and the active Cirolana borealis utilising $1.04 \mu \mathrm{mol} \mathrm{h} \mathrm{h}^{-1} \mathrm{~g}^{-1} \mathrm{dwt}$ for the first $18 \mathrm{~h}$ (starved $C$. borealis $1.64 \mu \mathrm{mol} \mathrm{h}{ }^{-1} \mathrm{~g}^{-1} \mathrm{dwt}$ ) (de Zwaan \& Skjoldal 1979). The aerobic metabolism, measured as $\mathrm{MO}_{2}$, of $S$. entomon is lower than for many other crustaceans (Hagerman \& Szaniawska 1988),
Fig. 2. Saduria entomon. Concentration of haemolymph glucose after various periods of anoxia

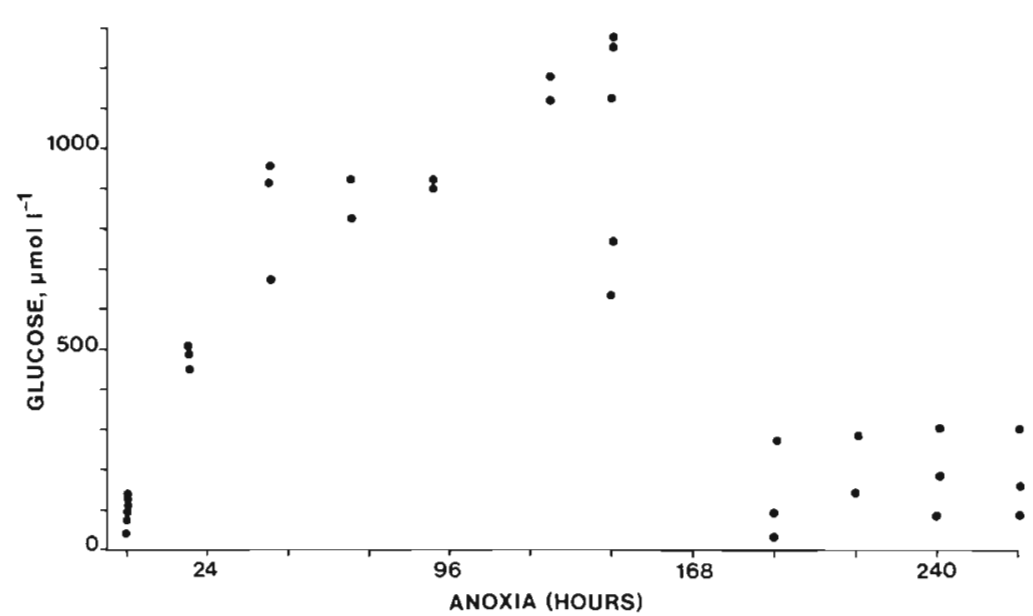


possibly because of the relatively heavy carapace. This low general metabolic rate is reflected in the generally low glycolytic flux. Furthermore, the decrease in glycolytic flux by a factor of 10 after about $100 \mathrm{~h}$ anoxia corresponds to the decrease in metabolic rate in the merostomate Limulis polyphemus mentioned by Gäde (1987), caused by the inhibitory effect of alanine on pyruvate kinase (see below)

Glycogen utilisation is reflected in increasing blood glucose levels during anoxia. Such an increase is a well-known phenomenon (Johnson 1985). The inverse relationship with glycogen in Saduria entomon confirms the changes in the glycolytic flux with time.

Exercise-driven as well as environmental anaerobic metabolism generally results in lactate accumulation in crustaceans (Bridges \& Brand 1980, de Zwaan \& Putzer 1985). It is confirmed here that exercise anaerobiosis under anoxic conditions results in lactate accumulation while evironmental anaerobiosis when the animal is inactive (the normal behaviour) does not result in lactate accumulation. The levels found under exercise anaerobiosis correspond to levels in Crangon crangon, Nephrops norvegicus and other crustaceans after some hours of hypoxia or after vigorous exercise (Bridges \& Brand 1980, Onnen \& Zebe 1983, Hagerman \& Szaniawska 1986). Lowery \& Tate (1986) noted that lactate levels of 42.6 to $49 \mathrm{mM}$ were lethal to the blue crab Callinectes sapidus. Such high levels were never noted in active Saduria entomon and no specimen died. The low, but rather stable anoxic lactate level for the normally inactive $S$. entomon indicates that the glycogenlactate pathway is never totally shut off. Carlsson \& Gäde (1986) found a similarly low lactate level for short-term anoxia $(24 \mathrm{~h})$ in the merostomate Limulus polyphemus. As stated by us earlier (Hagerman \& Szaniawska 1988) an oxygen debt sometimes occurs in $S$. entomon after a hypoxic/anoxic period. It is reasonable to assume that this oxygen debt occurs in individuals exhibiting exercise anaerobiosis and is caused by reoxidising accumulated lactate upon return to normoxic conditions. The rapid accumulation of lactate is typical for active, swimming or walking crustaceans. A somewhat comparable species is the isopod Cirolana borealis which accumulates lactate, similar to the active $S$. entomon, during a few hours foraging activity inside anoxic dead fish (de Zwaan \& Skjoldal 1979).

Under escape reactions, i. e. rapid beating of the abdomen, in for instance Homarus, Nephrops, or Crangon, an immediate mobilisation of high energy phosphagens (phosphoarginine, etc.) takes place, generating the necessary ATP in a very short time. The phosphagens are, however, depleted in seconds or a few minutes. For anoxic activity at a little lower level (swimming, eating) the lactate pathway can be used longer combined with an efficient utilisation of the last available oxygen in the water. The strategy of Saduria entomon using the glycogen-lactate pathway under exercise anaerobiosis under anoxia of comparatively short duration is thus an adaptation similar to most other crustaceans, maintaining a high ATP output per unit time even during anaerobic activity. On the other hand, the energy demand for the inactive, usually buried $S$. entomon is much lower, and in order to survive an extended anoxia it can turn to an anaerobic strategy not dependent on the glycogen-lactate pathway.

Alanine was found to be an important anaerobic endproduct in Saduria entomon, increasing steadily with time during anoxia and being the quantitatively most important endproduct after 40 to $60 \mathrm{~h}$ of anoxia. Increases in alanine during anoxia have only been found in a few cases in crustaceans. Normoxic alanine levels in blood and tissue were of the same order as reported for other crustaceans (Yamaoka \& Skinner 1976, de Zwaan \& Skjoldal 1979, Zebe 1982, Carlsson \& Gäde 1986). In Upogebia pugettensis and Callianassa californiensis alanine increased by around $50 \%$ after $24 \mathrm{~h}$ anoxia, but lactate dominated the whole time

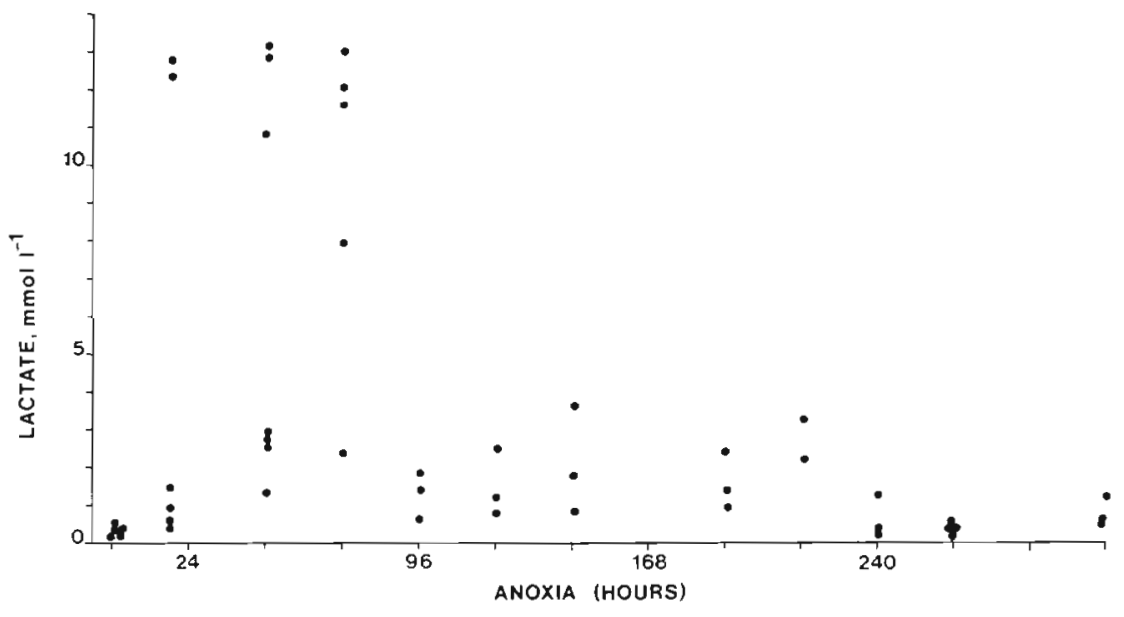

Fig. 3. Saduria entomon. Concentration of haemolymph lactate after various 
Fig. 4. Saduria entomon. Concentration of haemolymph alanine after various periods of anoxia

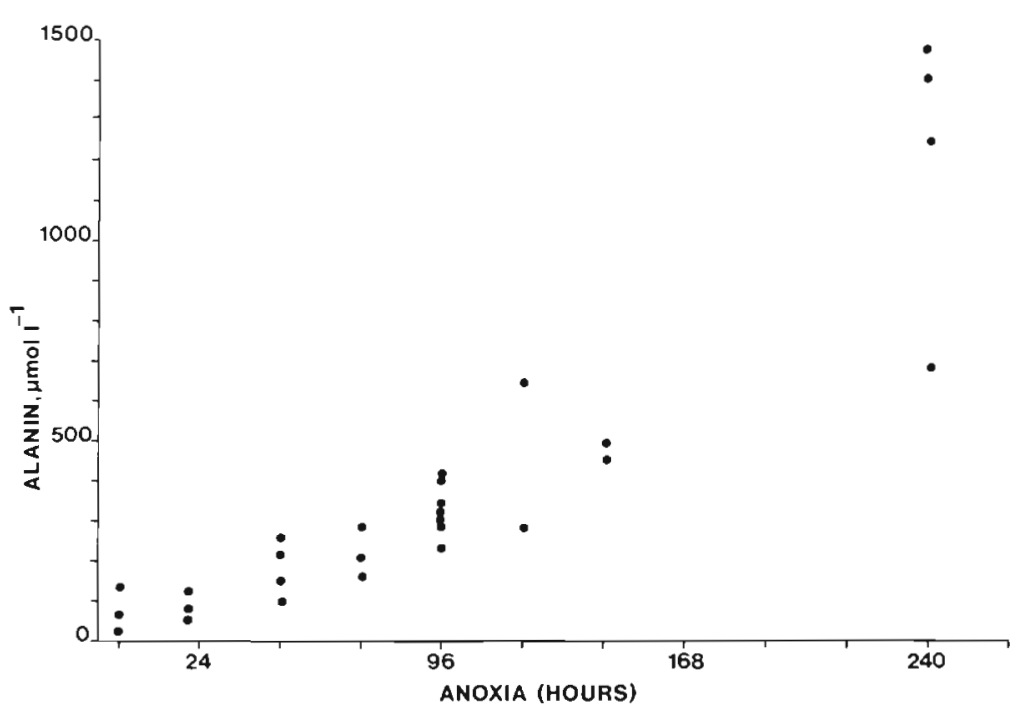

(Zebe 1982). In the merostomate Limulus polyphemus, Carlsson \& Gäde (1986) and Gäde \& Meinardus-Hager (1987) showed a considerable increase of alanine in muscle and hepatopancreas during $48 \mathrm{~h}$ anoxia while, similarly to $S$, entomon, lactate increased only slightly or not at all during environmental anoxia but much more during short-time ( 2 to $10 \mathrm{~min}$ ) exercise.

The absence of succinate shows also that the glycogen/ aspartate-succinate pathway so typical for many molluscs and annelids (de Zwaan \& Putzer 1985) is not important in Saduria entomon. Upogebia pugettensis and Callianassa californiensis were found to accumulate small quantities of succinate corresponding to the decrease in aspartate found in these species (Zebe 1982).

Alanine production via aspartate-aminotransferase and alanine-aminotransferase reactions (the aspartateshuttle as known from bivalves; de Zwaan \& Putzer 1985 ) is not possible in Saduria entomon due to the non-detectable level of aspartate. Instead it seems reasonable to assume that the mechanism suggested by Carlsson \& Gäde (1986) is operating: $\mathrm{NH}_{4}{ }^{+}$is used to oxidise $\alpha$-ketoglutarate by GluDH (glutamic dehydrogenase) to regenerate glutamate for the GPT (glutamic pyruvic transaminase) and to produce $\mathrm{NAD}^{+}$ (nicotinamide adenine dinucleotide). According to Carlsson \& Gäde (1986) the only endproduct of this would be alanine. There seem to be at least 2 advantages of using alanine as endproduct. Carlsson \& Gäde (1986) note that GluDH resembles the enzyme class of opine dehydrogenases (Livingstone et al. 1983) which occurs in certain bivalves and polychaetes and plays an important role in maintaining internal redox balance. A reduction of glycolytic flux, i.e. a reduction of anaerobic metabolism, seems to take place in Saduria entomon after ca $100 \mathrm{~h}$ of anoxia. It has been argued (Gäde \& Meinhardus-Hager 1987) that alanine, perhaps at above certain concentrations, inhibits the enzyme pyruvate kinase thus reducing the glycolytic flux. This would make it possible for $S$. entomon to withstand anoxic conditions for extended periods as the energy resources would last longer. However, such a flux reduction ought perhaps to be seen also in the
Fig. 5. Saduria entomon. Relative quantities of anaerobic metabolites in normoxia and in environmental anoxia (exercise anoxia, short and long-time anoxia). For further explanation, see text

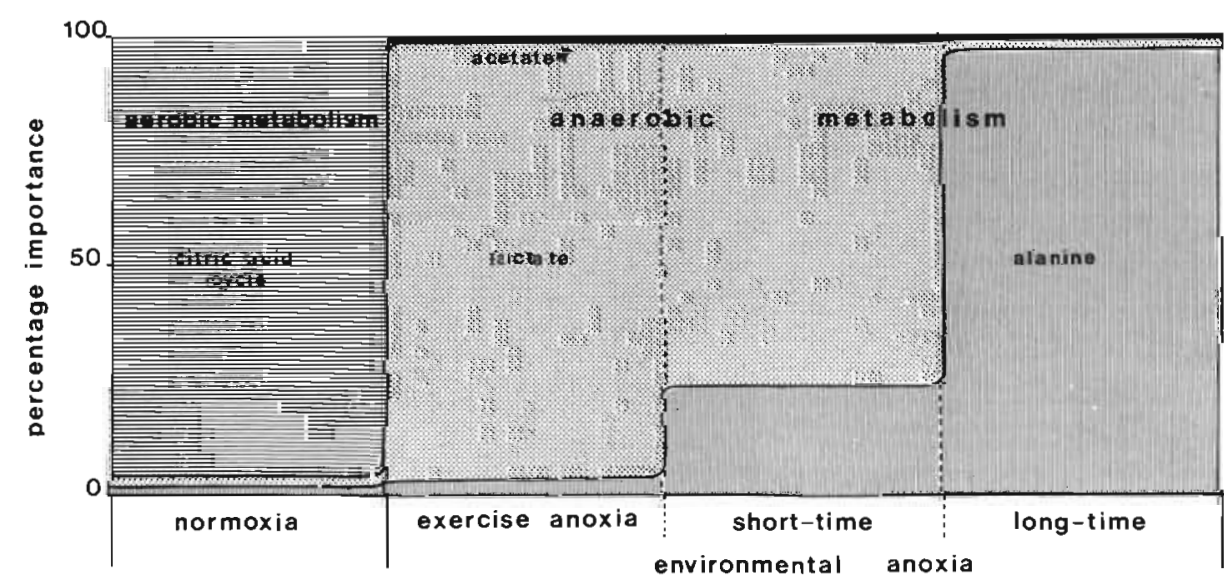


lactate concentrations changes and this is due to the already low lactate values, not so evident athough falling values can be seen after $240 \mathrm{~h}$ anoxia. There is a small possibility that the alanine might derive from protein catabolism, but de Zwaan \& Skjoldal (1979), among others, found no changes in protein levels under anaerobic conditions.

The aerobic-anaerobic strategy of Saduria entomon is summarised in Fig. 5. During very active behaviour, which can also take place under anoxic conditions, the anaerobic strategy is thus a typical crustacean strategy. the glycogen-lactate pathway. In the often anoxic Baltic bottom water and sediment, $S$. entomon has adapted its metabolism to a low level in a manner typical for buried, sluggish species, where requirements for spontaneous high activity are seldom. The anaerobic strategy suitable for this is the glycogen-alanine pathway making it possible for $S$. entomon to survive prolonged anoxia.

Acknowledgement. The project was supported by The Danish Science Research Council, Grant no 11-6218.

\section{LITERATURE CITED}

Bergmeyer, H. U. (ed.) (1985). Methods of enzymatic analysis, 3 rd edn. VCH Verlagsgesellschaft, Weinheim

Bridges, C. R., Brand, A. R. (1980). The effect of hypoxia on oxygen consumption and blood lactate levels of some marine crustaceans. Comp. Biochem. Physiol. 65 A: 399-409

Carlsson, K.-H., Gäde, G. (1986). Metabolic adaptation of the horseshoe crab, Limulus polyphemus, during exercise and environmental hypoxia and subsequent recovery. Biol. Bull mar biol. Lab., Woods Hole 171 217-235

Gäde, G. (1987). Leben ohne Sauerstoff: die Rolle der anaeroben Glykolyse bei aquatischen wirbellosen Tieren. Verh. dt. zool. Ges. 80: 93-110

Gäde, G., Meinardus-Hager, G. (1987). Anaerobic energy metabolism in Crustacea, Ziphosura and Mollusca: lactate fermentation versus multiple fermentation products. Zool. Beitr. N. F. 30: 187-203

This article was submitted to the editor
Gardner, W. S., Miller, W. H. (1980). Reverse phase liquid chromatographic analysis of amino acids after reaction with o-phthalaldehyde. Analyt. Biochem. 101 61-65

Hagerman, L., Szaniawska, A. (1986). Behaviour, tolerance and anaerobic metabolism under hypoxia in the brackish water shrimp Crangon crangon. Mar Ecol. Prog. Ser. 34: $125-132$

Hagerman, L., Szaniawska, A. (1988). Respiration, ventilation and circulation under hypoxia in the glacial relict Saduria (Mesidotea) entomon. Mar. Ecol. Prog. Ser. 47: 55-63

Johnson, I. T (1985). Studies on some responses of Carcinus maenas (L.) and other brachyurans to hypoxia and aerial exposure. Ph. D. thesis, Univ. of Hull

Livingstone, D. R., Zwaan, A. de, Leopold, M., Marteyn, E (1983). Studies on the phylogenetic distribution of pyruvate oxidoreductase. Biochem. Syst. Ecol. 11: 415-425.

Lowery, T A. Tate, L. G. (1986). Effect of hypoxia on haemolymph lactate and behaviour of the blue crab Callinectes sapidus Rathbun in the laboratory and field. Comp. Biochem. Physiol. 85A: 689-692

Onnen, T., Zebe, E. (1983). Energy metabolism in the tail muscles of the shrimp Crangon crangon during work and subsequent recovery. Comp. Biochem. Physiol. 74A: 833-838

Weber, R. E., van Marrewijk, W. J. A. (1972). Free amino acids in the brown shrimp Crangon crangon and their osmoregulatory significance. Neth. J. Sea Res. 5: 391-415

Vooys, C. G. N. (1987). Adaptation to anaerobic metabolism in two mussel species, Mytilus edulis and Mytilus galloprovincialis, from the tidal zone at Arcachon Bay, France. Neth. J. Sea Res. 21. 17-23

Yamaoka, L. H., Skinner, D. M. (1976). Free amino acid pool in muscle and hemolymph during the molt cycle of the land crab, Gecarcinus lateralis. Comp. Biochem. Physiol. 55A: $129-134$

Zebe, E. (1982). Anaerobic metabolism in Upogebia pugettensis and Callianassa californiensis (Crustacea, Thalassinidae). Comp. Biochem. Physiol. 72B: 613-617

de Zwaan, A., Skjoldal, H. R. (1979). Anaerobic energy metabolism of the scavenging isopod Cirolana borealis (Lilljeborg). J. comp. Physiol. 129: 327-331

de Zwaan, A., Putzer, V (1985). Metabolic adaptations of intertidal invertebrates to environmental hypoxia (a comparison of environmental anoxia to exercise anoxia). In: Laverack (ed.) Physiological adaptations of marine animals. The Company of Biologists, Cambridge, p. 33-62

Manuscript first received: April 13, 1989

Revised version accepted: September 20, 1989 